\title{
Safety Culture in Financial Trading: An Analysis of Trading Misconduct Investigations
}

\author{
Meghan P. Leaver ${ }^{1} \cdot$ Tom W. Reader ${ }^{1}$
}

Received: 30 June 2016/ Accepted: 5 February 2017/Published online: 22 February 2017

(C) The Author(s) 2017. This article is published with open access at Springerlink.com

\begin{abstract}
High-profile failures in financial trading have led to interest in how the culture of the industry produces risky and unethical behaviours among traders. Yet, there is no established theoretical framework for studying this: we apply safety culture theory to examine ten recent highprofile trading mishaps investigated by the UK financial regulator. The results show that the dimensions of safety culture (e.g. Management Commitment to Safety, Systems and procedures) used to understand organisational accidents in domains such as aviation also explain failures in Risk Management within financial trading organisations. This counters narratives focusing on traders who are unethical 'rule breakers', and emphasises the value of a systemic approach, whereby safety culture theory is used to explain why risky behaviours in financial trading occur. Safety culture therefore provides a conceptual basis for further research on risky and unethical behaviours in financial trading, alongside providing insights for possible intervention.
\end{abstract}

Keywords Safety culture · Failure · Risk-taking · Financial trading $\cdot$ Regulation $\cdot$ Culture measurement

Meghan P. Leaver

m.p.leaver@1se.ac.uk

Tom W. Reader

t.w.reader@1se.ac.uk

1 London School of Economics, 3, Queens House, 55/56

Lincoln's Inn Fields, London WC2A 3LJ, UK

\section{Introduction}

A series of large-scale failures to manage risk in the financial trading sector have led to multi-million dollar losses and fines (e.g. at Societe General, UBS, JPMorgan) and a focus on organisational culture within companies operating in the industry (Ashby et al. 2012; Palermo et al. 2016). This interest has arisen due to the role of unethical and risky behaviours (e.g. rogue trading, mis-selling, systemic rate rigging) in causing such failures (Greener 2006), with these practices being viewed as reflective of the 'values and the situational experience of a multitude of organisational agents' (Power 2009, p. 854).

Thus, culture change has been identified as a way to restore trust in financial institutions, improve Risk Management and avoid future failures (Parliamentary Commission on Banking Standards 2013). Yet, to achieve this, it is necessary to provide a clear conceptualisation of how the cultures of financial trading organisations produce risky and unethical behaviours and what a desirable culture might be. Various 'dimensions' of culture have been suggested (e.g. leadership, governance, competency, controls, rewards, risk appetite), yet descriptions remain atomistic and poorly defined (Power et al. 2013; Ring et al. 2016). This means there is little standardisation for how organisational culture is conceptualised in financial trading and, as a consequence, an incomplete and disjointed understanding of the factors that underlie risky and unethical behaviours.

To address this issue, the current article applies 'safety culture' theory to conceptualise and explain failures to manage risk within financial trading. Safety culture refers to beliefs (e.g. management priorities) and practices (e.g. risk-taking, protocols) for managing safety in high-risk organisations (e.g. aviation, health care, nuclear power, 
military) (Cooper 2000; Guldenmund 2000; Mearns et al. 2001; Pidgeon 1998; Reiman and Oedewald 2004). Although different approaches exist to theorise and measure organisational culture (Cameron and Quinn 2005; Erez and Gati 2004; Hofstede et al. 1990), safety culture has become the dominant theory used to understand how cultural factors determine risk practices in industries that must balance competing demands of productivity and safety (Glendon and Stanton 2000; Nordlöf et al. 2015). This is because safety culture explains how social environments directly influence risk practices and because problems in safety culture often underlie mishaps within other high-risk domains (e.g. aviation, health care, energy). Although financial trading is not a safety critical industry, mishaps are highly damaging for organisations and economies, and their causes are similar to those in other high-risk industries (e.g. managerial pressure to increase profit, ineffective procedures).

Thus, in this article, we examine whether safety culture theory also provides a useful conceptual framework for explaining and theorising failures to manage risk in financial trading. We do this through analysing ten highprofile investigations (conducted by the UK Financial Conduct Authority) of Risk Management within financial trading organisations. The purpose is to establish whether safety culture theory can provide a coherent account of why large-scale failures in financial trading organisations occur, and through drawing on this literature, to outline potential future steps for research and intervention.

\section{Financial Trading and Safety Culture}

Financial trading organisations buy and sell products (e.g. equities, physical commodities) in order to hedge existing risk, capitalise on arbitrage opportunities, speculate on market volatility and enhance their portfolios (e.g. risk position and profit). Financial trading is increasingly conceptualised as similar to a high-risk industry (Sutcliffe 2011; Young 2011), with risk constantly being monitored and when possible hedged. However, an important distinction is that, unlike many high-risk industries, the success of financial trading hinges on overt risk-taking by traders (as it leads to competitive advantage and potential profit). This feature is consistent with Amalberti's (2013) description of an 'ultra-resilient' organisation, where, rather than engineer risk out of the system, risk is managed through improving employee skills and system design (Amalberti 2013).

Yet, whilst some risk-taking is essential for success in financial trading organisations, unimpeded risk-taking can be highly destructive. Investigations into large-scale failures within financial trading organisations have highlighted problems with 'rogue traders' who manipulate rules and
Systems in order to gain short-term advantage (but with long-term costs). Although popular narratives have focused on the characteristics and unethical activities of 'rogue traders' as underlying financial scandals (Gapper 2011), academic research increasingly focuses on the organisational cultures that cultivate and allow risky and unethical trader activities (Gilligan 2011; Jennings 2008).

This is because such behaviours are a product of the practices that are encouraged, rewarded and penalised by trading firms (Chen et al. 1997; Kaptein 2011; Saini and Martin 2009). For example, research in finance has focused on the importance of 'fit' between the values of employees and their organisations for shaping ethical practices (Van Hoorn 2015), on tendencies for dishonesty with banking (Cohn et al. 2014), stigmatisation of industry practices (Roulet 2014) and the need for professionals and regulators to monitor and improve the culture of financial organisations (IIF 2009; Sants 2010; Wheatley 2012).

Yet, further description and theoretical analyses are required of what an 'appropriate' culture in financial trading is comprised of (Mcconnell and Blacker 2013; Ring et al. 2016). In particular, it is necessary to develop a cultural framework that is 'reduced and simplified to some observable properties that can be acted upon and audited by others' (Ashby et al. 2012, p. 18), for example in terms of rigorously determined conceptual underpinnings, distinct cultural dimensions and associations between these and risky behaviours by traders. To achieve this, scholars have drawn parallels between financial trading and other industries where risk-taking is sometimes necessary, but hugely damaging if not managed effectively: for example, aviation, nuclear power or health care (Young 2011). Within such industries, the concept of 'safety culture' is widely used to describe, explain and assess risk-related activities (Noort et al. 2015; Singer et al. 2009), and there may be value in applying this theoretical framework to financial trading. We explore this below.

\section{Safety Culture}

Safety culture is a safety-related facet of organisational culture and refers to the beliefs (e.g. on the priorities of management) and practices (e.g. risk-taking, protocols) within organisations that influence how risk and safety are managed (Cooper 2000; Guldenmund 2000; Mearns et al. 2001; Pidgeon 1998; Reiman and Oedewald 2004). The concept of safety culture became prominent due to it being identified as a casual factor in various catastrophic accidents (e.g. Chernobyl, NASA Challenger, Piper Alpha). In these cases, poor risk practices at an operational level (e.g. ignoring protocols, disregarding risk) were shown to be influenced by cultural norms that were determined by organisational and industry characteristics (e.g. rewards 
Systems, management priorities, regulation) (Paté-Cornell 1993; Pidgeon 1991; Zohar 1980). This was a significant observation, because it moved academic and practical theorisations on why organisational accidents occur away from a focus on individual employees (e.g. 'error', 'incompetence' or 'disregard for safety') and instead to the Systems and environments in which they operate (Reason 1998).

Over a period of 30 years, safety culture has become the dominant theoretical lens through which to understand how organisational culture shapes risk practices (Antonsen 2012; Strauch 2015; Zohar 2010). Although many theories and measurements exist for studying organisational culture and behaviour (Ashkanasy et al. 2000), safety culture focuses upon explaining why organisational employees engage in risky and unethical behaviours, and how these can lead to mishaps. Thus, for industries in which Risk Management is central to delivery, and where failures to effectively manage risk can lead to catastrophic failure, safety culture is valuable both theoretically and practically. Theoretically, it is useful in terms of helping organisations to understand how their social environments determine and shape the ethical and risk-related behaviours of employees. Practically, through safety culture measurement, it allows organisations to monitor their culture and to identify whether the organisational conditions that influence mishaps are positive or changing.

The validity of this approach is demonstrated by research showing safety culture to be associated with safety outcomes and risky activities (Clarke 2006; Hajmohammad and Vachon 2014). Indeed, safety culture measurement and improvement has become an integral part of Risk Management within domains such as health care, aviation, offshore oil and gas production, and nuclear power (Carroll 1998; Mearns et al. 2001; Reader et al. 2015; Weaver et al. 2013). Yet, no comparable approach exists for financial trading, and in the context of financial organisations being required to monitor and improve Risk Management and organisational culture (IIF 2009; Parliamentary Commission on Banking Standards 2013), safety culture theory appears useful for the following three reasons.

First, the approach of safety culture theory-to conceptualise risk-related behaviours by organisational employees as a product of the norms and values within a given system-may be insightful for understanding poor practices within financial trading. Rather than focusing on the behaviour of individual 'bad apples', safety culture theory focuses on how failures to manage risk reflect the normative tendencies and perceived priorities of an organisation (e.g. on pressures related to production versus safety) (Guldenmund 2000), and are representative of the robustness of Systems and procedures for managing risk (e.g. just culture) (Dekker 2012). In particular, safety culture appears relevant to financial trading because similar factors as those found to underlie mishaps in safety critical domains (e.g. reward structures, poorly designed Systems, skill deficits, unclear boundaries of acceptable behaviour) have been identified as important in cases of financial mismanagement and rogue trading (Land et al. 2014; Sims and Brinkmann 2003). Yet, in financial trading, no coherent framework exists for describing how organisational culture influences risky and unethical behaviours (Power et al. 2013; Ring et al. 2016). Safety culture provides an initial and well-established foundation for doing this.

Second, scholars have outlined a number of core 'latent' dimensions that capture the key characteristics of safety culture (e.g. Management Commitment to Safety). This is useful, because it allows for a more nuanced understanding of how different aspects of safety culture impact upon workplace activity, why risky and unethical behaviours are occurring, and what steps could be taken to reduce this. For example, where organisations have a culture of penalising those who make mistakes or slow down productivity for safety reasons, employees are less likely to report safety problems and near misses (Dekker 2012). It is beyond the scope of this article to list and review all safety culture studies; however, to illustrate, Table 1 lists the dimensions of safety culture used in ten prominent empirical studies and three literature reviews since 1999.

Although the micro-dimensions used to measure safety culture vary according to each paper, at a macro-level, conceptualisations of safety culture have a high degree of overlap. As summarised in Box 1, over-arching dimensions used to measure safety culture are Management Commitment to Safety (e.g. perceptions of staff for the managerial expectations on risk-related behaviours), risk handling (e.g. responding to error, risk-taking behaviours), Rules and Regulation (e.g. safety protocols), Systems (e.g. policies, incident reporting) and collaboration (e.g. communication, teamwork on safety). These constructs appear especially relevant to describing the cultural dimensions that account for risky and unethical behaviours in financial trading. For example, in the case of the Barclays Plc. rate-rigging misconduct, the Financial Conduct Authority (FCA) indicated that Systems and control failings, a conflict between organisational goals and organisational stability (e.g. to make profit), and weakly perceived management commitment to effectively manage risk catalysed the trading misconduct. Thus, the specific psychometric dimensions of safety culture used to understand problems in Risk Management within other industries may provide explanatory insight into the different forms of risky behaviour observed in financial trading.

Third, within the financial trading industry professionals and regulators have called for the need to establish guidelines to monitor and improve the 'risk culture' of 
Table 1 Literature review of safety culture dimensions

\begin{tabular}{|c|c|c|c|c|}
\hline References & Domain & Methodology & Dimensions & Interesting finding \\
\hline $\begin{array}{l}\text { Håvold } \\
\text { (2010) }\end{array}$ & Fishing vessels & $\begin{array}{l}\text { Safety culture questionnaire, } 50 \\
\text { questions-distributed to experts in EU }\end{array}$ & $\begin{array}{l}\text { Attitudes towards } \\
\text { Rules and } \\
\text { Regulations } \\
\text { Safety training and } \\
\text { drills } \\
\text { Job satisfaction } \\
\text { Fisherman's safety } \\
\text { attitude } \\
\text { Conflict between } \\
\text { work and safety } \\
\text { Pressure } \\
\text { Management safety } \\
\text { attitude }\end{array}$ & $\begin{array}{l}\text { Safety attitude of management had a } \\
\text { strong influence on a company's safety } \\
\text { policy-fisherman not involved in } \\
\text { accident showed more positive attitudes } \\
\text { towards safety culture }\end{array}$ \\
\hline $\begin{array}{l}\text { Jeffcott } \\
\text { et al. } \\
(2006)\end{array}$ & Railway & $\begin{array}{l}\text { Two-year qualitative study, } 40 \text { interviews } \\
\text { and } 50 \text { focus groups with } 500 \text { employees } \\
\text { in } 4 \text { organisations }\end{array}$ & $\begin{array}{l}\text { Stakeholder } \\
\text { relationships } \\
\text { Management } \\
\text { commitment } \\
\text { Performance regime } \\
\text { Blame and } \\
\text { culpability } \\
\text { Knowledge } \\
\text { management } \\
\text { Organisational } \\
\text { learning } \\
\text { Resources } \\
\text { Morale } \\
\text { Homogeneity of } \\
\text { culture }\end{array}$ & $\begin{array}{l}\text { How safety culture influences trust within } \\
\text { the organisation-trust is key to safety } \\
\text { performance } \\
\text { TOCs do not approach the classical 'safe' } \\
\text { organisation model (e.g. they exhibit a } \\
\text { rigid rather than flexible hierarchy and } \\
\text { procedures, deficiencies relating to } \\
\text { perceptions of management } \\
\text { commitment) }\end{array}$ \\
\hline $\begin{array}{l}\text { Goncalves } \\
\text { Filho et al. } \\
(2010)\end{array}$ & Petrochemicals & $\begin{array}{l}\text { Questionnaire measuring } 5 \text { aspects of OSC } \\
\text { in } 23 \text { petrochemical companies, adopting } \\
\text { the model of Hudson (2001) }\end{array}$ & $\begin{array}{l}\text { Information } \\
\text { (incident } \\
\text { reporting) } \\
\text { Organisational } \\
\text { learning } \\
\text { Involvement } \\
\text { (participation of } \\
\text { employees) } \\
\text { Commitment } \\
\text { (planning, } \\
\text { priorities) } \\
\text { Communication }\end{array}$ & $\begin{array}{l}\text { No theoretical or empirical research on } \\
\text { safety culture in this industry-this study } \\
\text { shows that the model of Hudson (2001) } \\
\text { and the revised framework can identify } \\
\text { levels of safety culture maturity in this } \\
\text { domain }\end{array}$ \\
\hline $\begin{array}{l}\text { Olsen } \\
\quad(2010)\end{array}$ & $\begin{array}{l}\text { Healthcare and } \\
\text { petroleum } \\
\text { sectors }\end{array}$ & $\begin{array}{l}\text { Questionnaires, } 1919 \text { (55\% return) in } \\
\text { health care and } 1806 \text { ( } 52 \% \text { return) in Oil } \\
\text { and Gas }\end{array}$ & $\begin{array}{l}\text { Organisational } \\
\text { management } \\
\text { support for safety } \\
\text { Transitions and } \\
\text { teamwork across } \\
\text { units } \\
\text { Supervisor/manager } \\
\text { expectations and } \\
\text { actions promoting } \\
\text { safety } \\
\text { Learning, feedback } \\
\text { and improvement } \\
\text { Teamwork within } \\
\text { units }\end{array}$ & $\begin{array}{l}\text { Testing the feasibility of cross-industrial } \\
\text { structural model of identifying general } \\
\text { safety climate concepts }\end{array}$ \\
\hline
\end{tabular}


Table 1 continued

\begin{tabular}{|c|c|c|c|c|}
\hline References & Domain & Methodology & Dimensions & Interesting finding \\
\hline $\begin{array}{l}\text { Lu and } \\
\text { Yang } \\
(2011)\end{array}$ & $\begin{array}{l}\text { Passenger } \\
\text { Ferry }\end{array}$ & Survey data from 155 experts in Taiwan & $\begin{array}{l}\text { Safety policy } \\
\text { Safety motivation } \\
\text { Emergency } \\
\text { preparedness } \\
\text { Safety training } \\
\text { Safety } \\
\text { communication }\end{array}$ & $\begin{array}{l}\text { Study provides empirical evidence of the } \\
\text { importance of safety climate in } \\
\text { explaining worker's safety behaviours in } \\
\text { passenger ferry operations }\end{array}$ \\
\hline $\begin{array}{l}\text { Reader and } \\
\text { O'Connor } \\
(2014)\end{array}$ & $\begin{array}{c}\text { Air traffic } \\
\text { control }\end{array}$ & $\begin{array}{l}\text { Psychometric properties of SC model } \\
\text { (ATM) were examined in } 17 \text { countries, } \\
\text { from } 4 \text { distinct regions (North, East, } \\
\text { South, West) - expert staff }(n=5176) \\
\text { and management staff }(n=1230)\end{array}$ & $\begin{array}{l}\text { Management } \\
\text { Commitment to } \\
\text { Safety } \\
\text { Collaborating for } \\
\text { safety } \\
\text { Incident reporting } \\
\text { Communication } \\
\text { Colleague } \\
\text { commitment } \\
\text { Safety support }\end{array}$ & $\begin{array}{l}\text { Demonstrated for the first time that when } \\
\text { safety culture is tailored to specific } \\
\text { industry, they can operate consistently } \\
\text { across national borders }\end{array}$ \\
\hline $\begin{array}{l}\text { Lee and } \\
\text { Harrison } \\
(2000)\end{array}$ & $\begin{array}{l}\text { Nuclear power } \\
\text { stations }\end{array}$ & $\begin{array}{l}\text { 120-item questionnaire in three nuclear } \\
\text { power stations. Seven focus groups, each } \\
\text { composed of } 10-12 \text { staff and addresses } \\
\text { attitudes and behaviour }\end{array}$ & $\begin{array}{l}\text { Confidence in safety } \\
\text { (e.g. control } \\
\text { measures, safety } \\
\text { standards) } \\
\text { Job satisfaction (e.g. } \\
\text { trust in colleagues) } \\
\text { Participation (e.g. } \\
\text { perceived } \\
\text { empowerment) } \\
\text { Risk (e.g. } \\
\text { organisational } \\
\text { risk-taking, risk } \\
\text { versus } \\
\text { productivity) } \\
\text { Safety rules (e.g. } \\
\text { complexity of } \\
\text { instructions) } \\
\text { Stress (e.g. personal } \\
\text { stress, job } \\
\text { security) } \\
\text { Timing/selection } \\
\text { (e.g. quality of } \\
\text { training) }\end{array}$ & $\begin{array}{l}\text { Personnel safety surveys can usefully be } \\
\text { applied to deliver a multi-perspective, } \\
\text { comprehensive and economical } \\
\text { assessment of the current state of a safety } \\
\text { culture and explored the dynamic of } \\
\text { inter-relationships of its 'working parts' }\end{array}$ \\
\hline $\begin{array}{r}\text { Ek et al. } \\
(2003)\end{array}$ & $\begin{array}{c}\text { Air traffic } \\
\text { control }\end{array}$ & $\begin{array}{l}\text { Observations of daily work, COPSOQ } \\
\text { questionnaire with } 95 \text { questions } \\
\text { representing } 9 \text { dimensions, standardised } \\
\text { interview with } 9 \text { employees at each } \\
\text { control centre }\end{array}$ & $\begin{array}{l}\text { Working situation } \\
\text { Communication } \\
\text { Reporting } \\
\text { Justness } \\
\text { Flexibility } \\
\text { Learning } \\
\text { Safety-related } \\
\text { behaviour } \\
\text { Attitude to safety } \\
\text { Risk perception }\end{array}$ & $\begin{array}{l}\text { Safety culture varies across locations and } \\
\text { personnel levels. All groups felt that they } \\
\text { had not received enough training in how } \\
\text { the communication should function in } \\
\text { emergencies. Managers tend to be very } \\
\text { positive in their reports of safety culture }\end{array}$ \\
\hline
\end{tabular}


Table 1 continued

\begin{tabular}{|c|c|c|c|c|}
\hline References & Domain & Methodology & Dimensions & Interesting finding \\
\hline $\begin{array}{l}\text { Wiegmann } \\
\text { et al. } \\
\text { (2004) }\end{array}$ & $\begin{array}{l}\text { Theoretical } \\
\text { literature } \\
\text { analysis (all } \\
\text { domains) }\end{array}$ & Systematic literature review & $\begin{array}{l}\text { Organisational } \\
\text { commitment } \\
\text { Management } \\
\text { commitment } \\
\text { Employee } \\
\text { empowerment } \\
\text { Rewards system } \\
\text { Reporting systems }\end{array}$ & $\begin{array}{l}\text { This study posits that there is considerable } \\
\text { disagreement among professionals on } \\
\text { how to define safety culture and to } \\
\text { differentiate it from safety climate }\end{array}$ \\
\hline $\begin{array}{l}\text { Farrington- } \\
\text { Darby } \\
\text { et al. } \\
(2005)\end{array}$ & Railway & $\begin{array}{l}\text { Group and individual semi-structured } \\
\text { interviews were employed. } 34 \\
\text { respondents were interviewed in } 6 \\
\text { groups (front-line operational staff who } \\
\text { volunteered) }\end{array}$ & $\begin{array}{l}\text { Communication } \\
\text { Rule dissemination } \\
\text { Pre-job information } \\
\text { Supervisor visibility } \\
\text { Equipment } \\
\text { Planners } \\
\text { competency } \\
\text { Perceived purpose } \\
\text { of paper work } \\
\text { Training methods }\end{array}$ & $\begin{array}{l}\text { Front-line actors have a strong underlying } \\
\text { sense that safety is not only their } \\
\text { responsibility_-but that they will look } \\
\text { for an 'easy and comfortable' way of } \\
\text { achieving task even if this involves } \\
\text { increased risk. Senior management were } \\
\text { seen as having considerable influence on } \\
\text { how easy or difficult it was to be 'safe' }\end{array}$ \\
\hline $\begin{array}{l}\text { Cox and } \\
\text { Cheyne } \\
(2000)\end{array}$ & $\begin{array}{l}\text { Offshore } \\
\text { environments }\end{array}$ & $\begin{array}{l}\text { Focus group discussions }(n=40) \text { using } \\
\text { both offshore and onshore personnel in } 3 \\
\text { organisations at } 6 \text { locations. } N=375 \\
\text { employees in groups ranging from } \\
\text { between } 3 \text { and } 12 \text { made up the focus } \\
\text { groups. } 83 \text { managers, } 181 \text { worked on } \\
\text { onshore, } 194 \text { offshore }\end{array}$ & $\begin{array}{l}\text { Management } \\
\text { commitment (e.g. } \\
\text { supervisor } \\
\text { support) } \\
\text { Priority of safety } \\
\text { Communication } \\
\text { (e.g. safety } \\
\text { information) } \\
\text { Safety rules (e.g. } \\
\text { complexity of } \\
\text { procedures) } \\
\text { Supportive } \\
\text { environment } \\
\text { Personal priorities } \\
\text { and need for safety } \\
\text { Personal } \\
\text { appreciation of } \\
\text { risk (e.g. risk- } \\
\text { taking behaviour) } \\
\text { Involvement (e.g. } \\
\text { participation) } \\
\text { Work environment } \\
\text { (e.g. equipment } \\
\text { and design) }\end{array}$ & $\begin{array}{l}\text { Most common dimensions were } \\
\text { management commitment, management } \\
\text { actions and the physical work } \\
\text { environment and safety issues and the } \\
\text { priority given to safety issues. This } \\
\text { helped construct a common taxonomy } \\
\text { for the industry-set of safety climate } \\
\text { assessment tools }\end{array}$ \\
\hline $\begin{array}{l}\text { Flin et al. } \\
\text { (2000) }\end{array}$ & Energy sector & $\begin{array}{l}\text { Review of methods and results from } \\
\text { industrial surveys, thematic basis of } 18 \\
\text { scales used to assess safety climate. } \\
\text { Thematic analysis following a literature } \\
\text { search, } 18 \text { published reports of safety } \\
\text { climate surveys }\end{array}$ & $\begin{array}{l}\text { Management } \\
\text { Safety system } \\
\text { Risk } \\
\text { Work pressure } \\
\text { Competence } \\
\text { Procedures/rules }\end{array}$ & $\begin{array}{l}\text { Suggests that the most typically assessed } \\
\text { dimensions relate to management }(72 \%) \text {, } \\
\text { the safety system }(67 \%) \text {, risk }(67 \%) \text {, in } \\
\text { addition themes relating to work pressure } \\
\text { and competence appear relevant }\end{array}$ \\
\hline
\end{tabular}


Table 1 continued

\begin{tabular}{|c|c|c|c|c|}
\hline References & Domain & Methodology & Dimensions & Interesting finding \\
\hline $\begin{array}{l}\text { Halligan } \\
\text { and } \\
\text { Zecevic } \\
(2011)\end{array}$ & Health care & $\begin{array}{l}\text { Literature review to identify the concepts } \\
\text { of safety culture prevalent in the } \\
\text { healthcare domain-studies published } \\
\text { between } 1980 \text { and } 2009.1324 \text { titles were } \\
\text { reviewed, } 1124 \text { unique abstracts, } 200 \text { full } \\
\text { text papers, } 139 \text { papers fully reviewed }\end{array}$ & $\begin{array}{l}\text { Leadership } \\
\text { commitment to } \\
\text { safety } \\
\text { Open } \\
\text { communication } \\
\text { founded on trust } \\
\text { Organisational } \\
\text { learning } \\
\text { A non-punitive } \\
\text { approach to } \\
\text { adverse event } \\
\text { reporting and } \\
\text { analysis } \\
\text { Teamwork } \\
\text { Shared belief in the } \\
\text { importance of } \\
\text { safety }\end{array}$ & $\begin{array}{l}\text { Attempts to determine a common set of } \\
\text { definitions and dimensions that can } \\
\text { enable researchers to better share } \\
\text { information and strategies to improve } \\
\text { methods }\end{array}$ \\
\hline $\begin{array}{l}\text { Clarke } \\
\text { (1999) }\end{array}$ & & $\begin{array}{l}\text { Questionnaire to elicit the perceptions of } \\
312 \text { rail staff using } 25 \text { 'dimensions' of } \\
\text { railway safety }\end{array}$ & $\begin{array}{l}\text { Management } \\
\text { Commitment to } \\
\text { Safety } \\
\text { Conflict between } \\
\text { work and safety } \\
\text { Rules and processes } \\
\text { Skills and attitudes } \\
\text { of employees } \\
\text { equipment }\end{array}$ & $\begin{array}{l}\text { The study shows that whilst there is a } \\
\text { shared perception of the importance of } \\
\text { safety across the group, inter-group } \\
\text { perceptions are not representative. } \\
\text { Furthermore, inter-group perceptions are } \\
\text { essential to mutual trust and the } \\
\text { foundation of positive safety culture }\end{array}$ \\
\hline
\end{tabular}

trading organisations (IIF 2009; Sants 2010; Wheatley 2012). This is seen as essential to restoring trust in financial institutions, improving Risk Management and avoiding catastrophic failures (House of Commons Treasury Committee 2009; Parliamentary Commission on Banking Standards 2013). Yet, there is little consensus within the literature on what an appropriate culture is or how it should be monitored and measured (Mcconnell and Blacker 2013; Ring et al. 2016). Within other high-risk industries, safety culture measurement is often used to benchmark risk-related practices within organisations in a given industry (Mearns et al. 2001). These data (e.g. surveys, incident reports, qualitative interviews) are used to develop a normative understanding of the industry, to recognise 'outlier' organisations (e.g. 'high' or 'low' performers) and to identify opportunities for learning and change within and between organisations. Thus, the methodology and concepts used in safety culture research provide a potential way forward for enhancing how risk culture is monitored and improved in the financial trading industry.

\section{The Current Study}

In summary, whilst large-scale failures to manage risk in financial trading do not necessarily lead to loss of life, they can seriously undermine economic and social structures. Safety culture theory may provide a useful framework for understanding the employee risk practices in financial trading that underlie these failures, outlining the specific dimensions of culture that influence behaviour in trading firms and measuring and benchmarking industry practices on risk. We examine the potential for this through analysing ten high-profile organisational failures in the UK financial trading industry. Specifically, through taking a safety culture perspective to systematically analyse Final Notices (FNs) ${ }^{1}$ issued by the Financial Conduct Authority (FCA) we:

1. Examine whether safety culture theory can account for employee risk practices in financial trading mishaps

2. Provide an initial framework of cultural dimensions for measuring and evaluating safety culture in financial trading

\footnotetext{
${ }^{1}$ FNs are comprehensive legal documentation available in the public domain that examine systematic investigations into instances of trading misconduct and set out action taken against companies or individuals for breaches of regulatory requirements. They provide an unbiased forensic analysis of the working context, nature of the violations and reasons for the breach.
} 
Box 1 Recognised components of safety culture

Management Commitment to Safety: Policies with regard to supervision and motivation of the workforce and the adherence to the rules (e.g. perceptions of staff for the managerial expectations on risk-related behaviours)

Blame and culpability

Employee participation (e.g. perceived empowerment)

Management safety attitude

Supervisor/management expectations

Morale

Safety motivation

Shared belief in the importance of safety

Risk: Policies with regard to which, when and how risks are evaluated (e.g. responding to error, risk-taking behaviours)

Appreciations or risk (e.g. risk-taking behaviour)

Confidence in safety (e.g. control measures, safety standards)

Rules and Regulations: Policies with regard to formal procedures and instructions (balanced by what is trained and how workers are recruited and selected). Basically, policies determining the structure of work (e.g. safety protocols)

Checklists

Planning

Rule dissemination

Safety rules (e.g. the complexity of instructions)

Safety training and drills

Systems: Policies with regard to how identified risks are avoided, reduced or controlled by design or layout (e.g. policies determining the choice of barriers that control present dangers and risks) and policies with regard to maintenance and inspection (e.g. policies, incident reporting) and how often, etc.)

Incident reporting (non-punitive)

Internal audits

Organisation of system access rights (e.g. access to information based on roles)

Resources

Systems alerts and controls

Systems maintenance (e.g. breach reports sent consistently)

Collaboration: Policies with regard to effective collaboration and interaction of (groups) of people (e.g. communication, teamwork on safety) Ability to speak up within the organisation

Transitions and teamwork across units

Trust in colleagues

Conflict between work and safety (e.g. risk appetite and performance goals)

3. Test the utility of these cultural dimensions through examining whether and how they influenced risk practices reported within the Final Notices

\section{Method}

The current study adopts safety culture theory to analyse ten Final Notices. Below we outline a Final Notice, the procedure for case selection and the analytical procedure used to analyse the cases.

A Final Notice is issued by the FCA when it has taken enforcement action against an individual or an organisation due to their conduct falling below the expected standards
(Financial Services Authority 2012). An FN sets out action taken against firms or individuals for regulatory breaches and explains the nature of and reason for the breach. The penalties and their publication in an $\mathrm{FN}$ are specifically intended to encourage change in the behaviour of the offender and deter future non-compliance by others. In this capacity, FNs provide a rich source of data for understanding how culture shapes employee risk practices in financial trading, and are a valuable learning tool for financial organisations. Although FNs focus on aspects of an incident such as managerial decision-making, technical Systems and controls and internal compliance checks, they have not previously been considered systemically within a culture framework (Bryce et al. 2013). 


\section{Case Selection}

The selection criteria were that:

1. The Final Notice related to a trading department (e.g. excluding retail banking, insurance funds, wealth management).

2. The events took place after the 2008 financial crisis (as this is when interest in culture and risk practices first emerged within the industry).

3. The magnitude of the financial penalty (>5 M GBP) were large enough that the event can be considered a significant organisational failure.

4. Repeated failures (e.g. LIBOR) were excluded after the first case in order to avoid skewing the results of the analysis.

Our final sample represents $0.47 \%$ of the total cases available in the FCA Final Notices database and $21 \%$ of the total cases where the penalty is equal to or greater than $5 \mathrm{M}$ GBP. In the final sample, six large banking institutions were represented (Barclays Plc., Credit Suisse, UBS AG, JPMorgan Chase Bank N.A., RBS, Toronto Dominion and RBS). Three of the institutions were repeatedly selected: Barclays Plc. (2), JPMorgan Chase Bank N.A. (2) and UBS AG (3). The problems ranged from individual rogue trading to market collusion and regulatory reporting infractions. To ensure the generalisability of safety culture as a theory for understanding trading mishaps, the case selection ensured that a wide range of offenders and problem types were analysed. To do this, we only included one instance of any particular type of event. For example, in the case of LIBOR rate rigging, five banks were penalised, only one bank was chosen in the cases, and we chose the first case detailed by the FCA. This ensured both variety and randomness in the sample of cases selected.

The selected FNs varied in terms of financial penalty; the average penalty amount is $£ 74.5 \mathrm{M}$, the lowest financial fine is $£ 5.6 \mathrm{M}$, and the highest fine is $£ 196.5 \mathrm{M}$. The summary of reasons for the various infractions also vary from manipulation of foreign currencies (UBS AG), inappropriate submission of regulatory data (Barclays Plc.) and failure to adequately assess and monitor the risks associated with trading activities (JPMorgan Chase Bank N.A.). The ten cases are summarised in Table 2.

\section{Procedure}

The method used to analyse the ten Final Notices was qualitative content analysis. This is consistent with accounting studies that used content analysis to examine risk disclosures (Linsley et al. 2006; Miihkinen 2012). The content analysis carried out in this paper follows the method presented by Kowal and O'Connell (2014) and is a more exploratory process than previous studies (Ring et al. 2016; Turner 1994).

Each FN case was loaded into NVivo11 and then analysed by two organisational psychologists: one with expertise in Risk Management in financial trading and the

Table 2 Selected Final Notice cases

\begin{tabular}{|c|c|c|c|c|}
\hline $\begin{array}{l}\text { Case } \\
\text { number }\end{array}$ & Organisation & Year & Fine & Description of misconduct \\
\hline 1 & JPMorgan Chase Bank N.A. & 2014 & $£ 222 \mathrm{M}$ & $\begin{array}{l}\text { Failed to control its London voice trading operations in the G10 spot and FX } \\
\text { market }\end{array}$ \\
\hline 2 & JPMorgan Chase Bank N.A. & 2013 & $£ 196.5 \mathrm{M}$ & $\begin{array}{l}\text { Losses caused by high-risk trading strategy, weak management of that trading and } \\
\text { an inadequate appreciation of risk }\end{array}$ \\
\hline 3 & UBS AG & 2012 & $£ 160 \mathrm{M}$ & $\begin{array}{l}\text { Misconduct relating to the calculation of EURIBOR, manipulation of certain } \\
\text { currencies and inter-dealer collusion }\end{array}$ \\
\hline 4 & Barclays Plc. & 2012 & $£ 85 \mathrm{M}$ & Inappropriate submissions following requests by derivative traders (LIBOR) \\
\hline 5 & UBS AG & 2012 & $£ 29.7 \mathrm{M}$ & $\begin{array}{l}\text { Rogue trading activity on exchange traded index future positions. Underlying } \\
\text { positions were disguised by the use of offsetting strategies, which had no } \\
\text { economic reality and no associated external risk position }\end{array}$ \\
\hline 6 & Barclays Plc. & 2014 & $£ 26 \mathrm{M}$ & $\begin{array}{l}\text { Failing to take reasonable care to organise and control its affairs responsibly and } \\
\text { effectively, with adequate Risk Management Systems (gold price fixing) }\end{array}$ \\
\hline 7 & UBS AG & 2009 & $£ 8 \mathrm{M}$ & Unauthorised foreign exchange and precious metals trading \\
\hline 8 & $\begin{array}{l}\text { Toronto Dominion Bank } \\
\text { (London Branch) }\end{array}$ & 2009 & $£ 7 \mathrm{M}$ & $\begin{array}{l}\text { Failing to conduct business with due care, skill and diligence-numerous and } \\
\text { serious failings in the Systems and controls concerning trading book pricing }\end{array}$ \\
\hline 9 & Credit Suisse & 2008 & $£ 5.6 \mathrm{M}$ & $\begin{array}{l}\text { Failing to conduct business with due skill, care and diligence. Failings relate to the } \\
\text { pricing of certain asset-backed securities }\end{array}$ \\
\hline 10 & $\begin{array}{l}\text { The Royal Bank of Scotland } \\
\text { Plc./N.V. ('RBS') }\end{array}$ & 2013 & $£ 5.6 \mathrm{M}$ & $\begin{array}{l}\text { Failing to accurately report trading transaction as a result of significant Systems } \\
\text { challenges post-takeover }\end{array}$ \\
\hline
\end{tabular}


other with expertise in safety research across a range of high-risk industries. The framework used to analyse the cases was derived from the five dimensions (and 25 subdimensions) of safety culture extracted from the literature review (see Table 1, Box 1). All ten FNs follow the FCA standard template. Cases were assessed in terms of whether they were consistent with the dimensions and sub-dimensions of safety culture listed in Box 1. The parts of the report that appeared to be associated with a dimension of safety culture were coded within NVivo. Each FN was analysed by a single coder (lead author), and five FNs were additionally coded by an organisational psychologist (second author) to ensure reliability.

\section{Analysis}

Prior to investigating the research questions, the reliability of the qualitative content analysis was established. To do this, the inter-rater reliability of the two raters (first and second author) was examined using a Cohen's kappa calculation in NVivo11. Cohen's kappa coefficient measures inter-rater agreement for two raters for qualitative (categorical) items such as safety culture dimensions. ${ }^{2}$ Overall, the reliability across the ten cases for the five safety culture dimensions was good and across the dimensions ranged from substantial agreement: Management Commitment to Safety $(k=0.80)$, Rules and Regulations $(k=0.67)$, Organisational Communication $(k=0.62)$ to moderate agreement: Systems $(k=0.53)$ and fair agreement: Risk Management $(k=0.26)$. Consistently low reliability was shown across all sub-dimensions.

In order to investigate the role of safety culture in financial trading, the following analyses were performed:

1. Establishing the role of safety culture in the Final Notices

To examine whether safety culture theory can account for employee risk practices in financial trading mishaps, we investigated the extent to which the safety culture dimensions listed in Box 1 were described in the FNs as underlying the problems leading to failures in Risk Management. Each case was read and any textual references to the predetermined set of safety culture dimensions were identified and classified in NVivo11.

2. Developing an initial framework of cultural dimensions for measuring and evaluating safety culture in financial trading

\footnotetext{
${ }^{2}$ It is suggested that kappa results can be interpreted as value $k \leq 0.01-0.2$ as none to slight, $k \leq 0.21-0.40$ as fair, $k \leq 0.41-0.60$ as moderate, $k \leq 0.61-0.80$ as substantial and $k \leq 0.81-1.00$ as almost perfect (Fleiss and Cohen 1973; McHugh 2012).
}

We further refined the safety culture framework in Box 1 in order to provide an initial framework of cultural dimensions for measuring and evaluating safety culture in finance trading (Box 2). We did this through an examination of the most commonly occurring dimensions within the cases (established in the first phase of analysis and reporting), as well as exploring rarely used dimensions across all the cases and creating a refined list of the relevant dimensions in this domain. Simply, where safety culture dimensions were identified within the FNs, these were included within the framework. Where they were absent, the dimensions were removed.

3. Examining how the dimensions of safety culture for financial trading relate to risk practices reported in the Final Notices

Finally, we examined the utility of the specific safety culture dimensions for explaining risk practices in financial trading. We did this through identifying parts of text in the report previously coded as being associated with a dimension of safety culture. We then analysed those segments of text in order to establish whether and how the specific activities identified as problematic within the FNs were influenced by the cultural dimension.

This required a more inductive approach (Braun and Clarke 2006), whereby associations between the safety culture dimensions and trading activities were identified. Specifically, for the segments of text coded in NVivo as referring to a safety culture dimension (in the first stage of analysis), a single coder (lead author) identified the patterns of trader activity that were reported and described. This was an iterative process, whereby themes of associations between the safety culture dimensions and trader activities emerged (and were logged in NVivo). A second coder (the second author) independently evaluated the generation of themes, and these were then refined and interpreted through further conceptualisation of how the safety culture dimensions might be argued to influence activity. This was done through reference to the broader literatures on safety culture and financial trading. The inductive phase of analysis helps to reveal themes or patterns specific to financial trading that emerge from the cases, and this in turn informs the creation of bespoke dimensions.

\section{Results}

\section{The role of safety culture in financial trading mishaps}

The content analyses of the Final Notices were found to yield rich data on how the organisational environment shaped behaviours in the featured organisations. For 
example, in eight of the cases, the perceived ability to speak up (Organisational Communication) was critical to embedding error and undermining mitigation opportunities within the offending organisations. In the case of Barclays Plc. (2012), the lack of ability to speak up was driven by factors such as: unwanted negative press (p. 3); 'internal political pressure' (p. 25); and a culture of secrecy 'if you breathe a word of this I'm not telling you anything else' (p. 21). It appears that these unsafe practices influenced traders' behaviour, leading to the continued submission of inaccurate data and manipulation of internal performance evaluation tools (e.g. profit and loss reports). To illustrate the context of the data collected and the types of problems codified across the safety culture dimensions and sub-dimensions, qualitative examples from the text are included in Table 3.

Table 3 illustrates that $25 \%$ of the assessed cases relate to the dimension of Organisational Communication and, within this dimension, the most common coded sub-dimension is the ability to speak up (23\%). The dimension 'Systems Implementation' was identified in $21 \%$ of the assessed cases, with Systems alerts and detection (11\%) and incident reporting (10\%) being the most common subdimensions. The least frequently identified dimension was Rules and Regulations (17\%). In terms of sub-dimensions of safety culture, the most common was rule dissemination $(16 \%)$ and safety training and drills (15\%). The sub-dimension checklists (Rules and Regulations) was not identified in any of the cases. Similarly, certain sub-dimensions were rarely coded such as: morale, blame and culpability (Management Commitment to Safety), confidence in safety (Risk Management), planning (Rules and Regulations) and internal audit (Systems). Table 3 indicates that there are rarely occurring sub-dimensions including confidence in safety, planning and internal audit.

In order to refine the safety culture framework for future use (e.g. to guide the development of a survey, root-cause analysis of trading incidents), a number of further interpretations were made, and we explore these in the following section.

\section{A framework of cultural dimensions for measuring and evaluating safety culture in financial trading}

Below we describe and present a refined safety culture framework, tailored to the financial trading domain. This framework is based on the preceding analysis, and in particular, the results are reported in Table 3.

First, it is noticeable that the absence of sub-dimensions (e.g. confidence in safety, planning and internal audit) may indicate that these are less relevant in the assessment of safety culture in the finance domain, and could be either removed in future iterations of the framework or tested through alternative methods (e.g. interviews).

Second, the content analysis of the sub-dimensions reveals that some sub-dimensions exhibit low inter-rater reliability. However, rather than removing the sub-dimensions, it may be that those which touch on similar issues could be combined in order to benefit the overall reliability. For example, resources and system maintenance may be combined, and safety training and rule dissemination might also be combined.

Lastly, the FCA notices highlight the influence of organisational incentives (e.g. bonuses) and opportunities for advancement as drivers of safety behaviour (e.g. in the LIBOR notices, the FCA indicates that it was commonplace for senior management to determine bonuses and career advancement based on the size of an individual trader's book). Although the literature search that informed the development of Box 1 does not explore power and monetary rewards (e.g. bonuses), there is likely benefit in studying the influence of rewards upon trading staff's safety behaviour. For example, research shows that, given the nature of leaders in an organisational setting, and their ability to dismiss or punish employees, it could be beneficial to explore the value placed on money relative to that of safety (Flin and Yule 2004; Zohar 2002). Therefore, we believe that this sub-dimension warrants inclusion in the safety culture framework and is most relevant to Management Commitment to Safety (Antonsen 2009).

Informed by the aforementioned findings and interpretations, a synthesis is presented in Box 2, where we offer a refined list of safety culture dimensions, tailored to the context of financial trading.

\section{Associations between safety culture dimensions and risk practices in financial trading}

We expand on Table 3 and Box 2, and consider (from a safety culture perspective) the various manifestations and poor employee risk activities that were captured in the analysis of the FNs. The purpose is to test and operationalise how the constructs that comprise safety culture theory impact behaviour within financial trading. Below we report on associations between safety culture dimensions and risk activities observed in the FNs, and also interpret these within the wider safety culture and financial trading literature. Crucially, the interpretative section allows us to effectively map the safety culture dimensions onto the observed behaviours in the FCA cases, and this promotes a more nuanced understanding of the relationship between safety culture and trading mishaps. 
Box 2 Components of safety culture in finance

Organisational Communication: Policies with regard to effective collaboration and interaction of (groups) of people (e.g. policies determining who should talk with whom about what)

Ability to speak up within the organisation

Transitions and teamwork across units

Trust in colleagues

Management Commitment to Safety: Policies with regard to supervision and motivation of the workforce and the adherence to the rules (e.g. what is acceptable behaviour and how deviations should be corrected)

Blame and culpability

Employee participation (e.g. perceived empowerment)

Management safety attitude

Supervisor/management expectations

Safety motivation

Shared belief in the importance of safety

Risk Management: Policies with regard to which, when and how risks are evaluated (e.g. what the present dangers and risks are and how they should be perceived and controlled)

Appreciations or risk (e.g. risk-taking behaviour)

Confidence in safety (e.g. control measures, safety standards)

Conflict between work and safety (e.g. risk appetite and performance goals)

Rules and Regulations: Policies with regard to formal procedures and instructions (balanced by what is trained and how workers are recruited and selected). Basically, policies determining the structure of work

Rule dissemination

Safety training and drills

System Implementation: Policies with regard to how identified risks are avoided, reduced or controlled by design or layout (e.g. policies determining the choice of barriers that control present dangers and risks) and policies with regard to maintenance and inspection (e.g. when (preventative vs corrective) and how often, etc.)

Incident reporting (non-punitive)

Organisation of system access rights (e.g. access to information based on roles)

Resources

Systems alerts and controls

Systems maintenance (e.g. breach reports sent consistently)

\section{Organisational Communication}

Communication on risk (e.g. discussing threats to safety, communicating procedures and changes and raising concerns) was found to underpin an effective safety culture. Across the FNs, organisations lacked a coherent communication plan for disseminating safety rules, procedures and training. A lack of clear training and guidance regarding internal policies of conduct was cited in nine of the ten cases reviewed. For example, at Barclays Plc., the FCA noted that 'the firms lack of specific training and guidance, given the absence of clear and sufficiently-tailored policies and procedures...meant that personnel may have been unaware of which conflicts of interest they should pay particular attention to...' and precipitated this particular failure (Barclays Plc., p. 3).

The absence of training and communication on best practices fostered confusion between the departments and a lack of clarity regarding the utility of new policies or collective regulatory responsibility. This meant that oftentimes, the operational staff overlooked their regulatory responsibilities (e.g. price testing) or continued to participate in the established risky practices (e.g. modifying the submissions data when asked by Front Office).

In terms of the wider literature, previous research shows good communication on organisational risks (e.g. as established through training) is critical to developing a strong safety culture (Olive et al. 2006), and it also appears important for conceptualising and assessing safety culture in financial trading (e.g. developing incident reporting Systems, change, clear communication protocols).

\section{Management Commitment to Safety}

The FNs provide numerous examples of the importance of Management Commitment to Safety in financial trading organisations. Key drivers of employee risk practices identified in the FNs were the behaviours and attitudes of 
Table 3 Safety culture dimensions and sub-dimensions identified in the FCA cases

\begin{tabular}{|c|c|c|c|}
\hline Dimensions & $\begin{array}{l}\text { Sub- } \\
\text { dimensions }\end{array}$ & Description & Example \\
\hline \multicolumn{4}{|c|}{$\begin{array}{l}\text { Organisational } \\
\text { Communication }\end{array}$} \\
\hline & $\begin{array}{l}\text { Ability to } \\
\text { speak up }\end{array}$ & $\begin{array}{l}\text { Refers to extent to which employees are } \\
\text { comfortable or perceived to be able (e.g. } \\
\text { organisational constraints) to voice } \\
\text { concerns inter-/intra-team }\end{array}$ & $\begin{array}{l}\text { 'Lack of product knowledge within the } \\
\text { collateral team which meant that no } \\
\text { effective challenge was made' }\end{array}$ \\
\hline & $\begin{array}{l}\text { Transitions } \\
\text { across teams }\end{array}$ & $\begin{array}{l}\text { Refers to the coordination of processes and } \\
\text { tasks within and between interdisciplinary } \\
\text { teams }\end{array}$ & $\begin{array}{l}\text { 'Work streams operated in silos; those } \\
\text { preforming the work lacked awareness of } \\
\text { the overall context' }\end{array}$ \\
\hline & $\begin{array}{l}\text { Trust in } \\
\text { colleagues }\end{array}$ & $\begin{array}{l}\text { The measure of confidence and competence } \\
\text { in team members }\end{array}$ & $\begin{array}{l}\text { 'These traders formed close, tightknit groups } \\
\text { or one-to-one relationships based upon } \\
\text { mutual benefit' }\end{array}$ \\
\hline
\end{tabular}

Coding frequency

$25(11 \%)$

Total

Management Commitment to Safety

Blame and culpability

Employee participation

Management safety attitude

Manager expectations

A measure of the culture of blame shifting or lack of acceptance of organisational responsibilities

The extent to which employees perceive they are able to contribute to decisions and organisational process

Management perceived prioritisation of safety and productivity

The perceived expectations of management to perform safely

Morale

The confidence, enthusiasm and discipline of the team at a specific time

Safety motivation

The reasons for demonstrating good or poor safety behaviour

Shared belief in the importance of safety

Total

Risk

Management
Appreciations of risk

Confidence in safety
The beliefs and values in regard to safety that learning originate from manager-directed joint

'Are we guilty of being part of the pack? You could say we are'

'Front office was able to input, change and approve FX trades with no effective challenge from the Back Office'

'Senior management at high levels within Barclays expressed concerns over this negative publicity'

'Senior management concerns in turn resulted in instructions being given by less senior managers at Barclays to reduce LIBOR submissions in order to avoid negative media comment'

'The external trader thanks Trader $G$ for Barclay's LIBOR submissions later that day; "Dude. I owe you big time! Come over one day after work and I'm opening a bottle of Bollinger",

'The authority was deliberately misled on one occasion'

'Although action plans were in place to improve processes for future months, no additional scrutiny of the March month-end valuation process was undertaken by $\mathrm{CIO}$ Finance or CIO VCG management'

'Barclays did not believe the submission of inaction taken as a result of gaining or losing asset value

LIBOR was an area of significant risk'

Business model placed significant reliance on the honesty of employees and the supervisory obligations of Desk Heads without taking steps to mitigate against the risk that employees would act incompetently or dishonestly' 
Table 3 continued

\begin{tabular}{|c|c|c|c|}
\hline Dimensions & $\begin{array}{l}\text { Sub- } \\
\text { dimensions }\end{array}$ & Description & Example \\
\hline & $\begin{array}{l}\text { Conflict } \\
\text { between } \\
\text { work and } \\
\text { safety }\end{array}$ & $\begin{array}{l}\text { Impacts the decision to meet performance } \\
\text { requirements (productivity) or to adhere to } \\
\text { the standard operating procedure (safety) }\end{array}$ & $\begin{array}{l}\text { 'At the direction of the SCP management, } \\
\text { they deliberately mismarked the SCP in } \\
\text { order to conceal what one trader believed to } \\
\text { be genuine losses' }\end{array}$ \\
\hline \multicolumn{4}{|l|}{ Total } \\
\hline \multicolumn{4}{|l|}{$\begin{array}{l}\text { Rules and } \\
\text { Regulations }\end{array}$} \\
\hline & Planning & $\begin{array}{l}\text { The existence of procedures to evaluate risks } \\
\text { and establish the necessary safety measures } \\
\text { for avoiding accidents }\end{array}$ & $\begin{array}{l}\text { 'Reassignments and reorganisations within } \\
\text { certain control functions, together with } \\
\text { remote supervision and demanding } \\
\text { workloads, exacerbated the situation' }\end{array}$ \\
\hline & $\begin{array}{l}\text { Rule } \\
\text { dissemination }\end{array}$ & $\begin{array}{l}\text { The availability (e.g. access) and distribution } \\
\text { of information in regard to safety rules } \\
\text { within and across the organisation }\end{array}$ & $\begin{array}{l}\text { 'Compliance replied with appropriate advice } \\
\text { by email, there is no record of wider } \\
\text { dissemination of the guidance or of steps to } \\
\text { ensure this was reflected in (JPMorgan's) } \\
\text { policies or controls' }\end{array}$ \\
\hline & Safety rules & $\begin{array}{l}\text { Refers to the existence of protocols and } \\
\text { procedures for operating safely during } \\
\text { routine and non-routine tasks }\end{array}$ & $\begin{array}{l}\text { 'Compliance reviews lacked depth and a } \\
\text { robust risk assessment process. The } \\
\text { monitoring (of international wealth } \\
\text { business) had limited impact on identifying } \\
\text { and improving the control framework' }\end{array}$ \\
\hline & $\begin{array}{l}\text { Safety training } \\
\text { and drills }\end{array}$ & $\begin{array}{l}\text { The existence of training programs or } \\
\text { opportunities to simulate situations where } \\
\text { employees face routine and non-routine } \\
\text { tasks }\end{array}$ & $\begin{array}{l}\text { 'The firm's lack of specific training and } \\
\text { guidance, given the absence of clear and } \\
\text { sufficiently-tailored policies and procedures } \\
\ldots \text { meant that personnel may have been } \\
\text { unaware' }\end{array}$ \\
\hline
\end{tabular}

\section{Incident} reporting

Internal audit

Organisation of system rights

Resources

System alerts and detections

System maintenance
A method of recording details of non-routine events that occur within the organisation that can undermine organisational safety and performance (e.g. human error, Systems error)

The provisions of independent assurance that Risk Management, governance and internal control processes are operating effectively

Segregation of access to system information and modifications based on job responsibilities

The efficient apportioning of time, capital and personnel

The capability of the system to accurately monitor and detect system abuse

The timely maintenance and modification of system controls and capabilities
Coding

frequency

$38(22 \%)$

'It failed appropriately to escalate issues that $19(10 \%)$ may have led to earlier detection of the pricing issues'

'Internal audit failed appropriately to follow up, finalise and report the finding that GMO were accepting market quotes from the front office as independent'

'There was confusion within GMO as to the segregation of duties and responsibilities in conducting the IPV process'

'CIO VCG needed to manually copy this data into its own price testing spreadsheet row by row. This resulted in data entry errors'

'There was no automatic filter in the trade input Systems which identified off market or large notional transactions and the amendment of a price'

'(Barclays) made no changes to its Systems and controls to take account of the BBA' 
senior management for prioritising safe operations. For example, at the direction of the management at JPMorgan Chase Bank N.A., traders falsely priced their positions in order to minimise published losses and benefit the bid-ask spread in the organisation's favour. Going further, when management at JPMorgan Chase Bank N.A. discovered the large, relatively illiquid positions, they did not immediately request a reduction in the positions and instead allowed the traders to take increasingly larger positions.

In all ten cases we analysed, the FCA cites insufficient scrutiny by the management tasked with overseeing trading strategy as a key factor in the occurrence of trading mishaps. A consistent pattern emerges of a lack of actual or perceived management prioritisation for safety in the cases (as enacted through behaviour, statements, Systems and procedures) shaping normative expectations on trader performance, and influencing trader risk-taking activities through this mechanism. This perhaps emphasises the importance of Management Commitment to Safety for creating the atmosphere and tone (e.g. attitudes towards issues around risk, error, blame) for the acceptability and unacceptability of risky and unethical practices.

In terms of the literature on safety culture, the influence of management prioritising production goals over safety upon risk-related activities is observed in many domains and is associated with safety activities (Zohar 2010). It has also been identified as crucial in incident investigations. For example, mishaps such as the Deep-water Horizon (DH) oil spill are somewhat analogous to the FNs (Reader and O'Connor 2014). In the case of the DH blowout, the National Commission (2011) reported that many of the riskier operational decisions were made due to a desire to save time, costs and ensure long-term viability of the well 'without full appreciation of the associated risks' (National Oil Spill Commission 2011, p. 223).

\section{Risk Management}

Key to an effective safety culture is a description, perception and acceptance of what the present dangers and risks to the organisation are (e.g. conflicts between performance and safety). A recurrent problem identified within the FNs was the failure of organisations to recognise and address incidents. For example, in the Toronto Dominion case, the FCA finds that the organisation 'failed to appropriately escalate issues that may have led to earlier detection of the pricing issues' (Toronto Dominion, p. 2). Similar key findings are listed in eight of the ten cases reviewed. Through not sharing, collecting or emphasising information on previous incidents and near misses, the likelihood of a future failure is increased. Furthermore, in the cases studied, the lack of a clear policy on reporting incidents or a dedicated feedback system discouraged front-line staff from reporting incident information, which negatively shaped risk escalation behaviours.

In relation to the safety culture and financial trading literature, this is consistent with research showing that poor internal management processes, general Systems, or a lack of willingness or ability of staff to escalate incidents can seriously hinder the collection of relevant risk data and undermine the development of robust Risk Management models (Bryce et al. 2013). In other industries, the implementation of a confidential incident and near-miss reporting system provides a means for the organisation to collect, identify and ameliorate risks within the system, and to provide a proactive measure of Risk Management that encourages employee participation, raises awareness, promotes adaptation and engenders social responsibility for safety (Jeffcott et al. 2006). Similar Systems are being developed in financial trading and would appear useful for developing the safety culture of trading organisations (Leaver and Reader 2016).

\section{Rules and Regulations}

The FNs illustrate numerous issues relating to Rules and Regulations, with issues around training and skills being particularly prominent. For example, an over-reliance on the technical knowledge of the traders exacerbated the failures described in the FNs. In the Credit Suisse case, the FCA points out that 'Undue reliance was placed in the technical ability and revenue contribution of certain Front Office staff, who were highly influential in down-playing price testing and variances' (Credit Suisse, p4). Front Office staff (e.g. traders) regularly circumvented the controls in place by exploiting their technical ability and expertise relative to the control teams, which centralised the decision-making on the floor. Lack of training or knowledge in the support teams shaped the practices of the risk control team (e.g. inability to challenge the Front Office strategies and the acceptance of inaccurate pricing data) and led to a situation where the trading support team tasked with challenging the Front office operated at a diminished capacity.

In the most obvious case of exploitation, the FCA notes that 'Within UBS the Operations Division (trading support) acted as a facilitation division rather than having a specific risk control mandate... There was a culture of helping the traders to clear breaks on the basis of the explanations they provided as opposed to challenging the traders and questioning whether their explanations were correct' (UBS AG, p4). In this case, problems arose as a result of the organisations approach to the first line of defence in Risk Management, which assumed skills those involved did not have (e.g. the ability to challenge the Front Office). 
The safety culture literature has indicated the importance of Rules and Regulations for influencing behaviour (Hopkins 2011; Lawton 1998; Reason et al. 1998), for example in terms of ensuring procedures reflect the work that is done within an organisation and ensuring safety procedures are followed. Rules and Regulations provide frameworks and protocols for controlling risk and are useful because they specify the expected minimum behavioural standards of employees. This appears also to have been the case in the FNs, indicating the importance of Rules and Regulations as a dimension of safety culture in financial trading.

\section{Systems Implementation}

Across the ten FCA cases, the Systems used to oversee and monitor the trading activity were identified as complex and fragmented. Within safety culture theory, Systems Implementation (e.g. policies, monitoring Systems) is crucial for ensuring organisations are able to identify risks and provide appropriate resources for effectively managing and ameliorating risk. The FNs revealed systematic problems in System Implementation, with 'overly complex and fragmented' reporting Systems undermining the ability of employees to detect and manage warning signals. For example, in the UBS AG case, the FCA noted that 'The Systems and controls in place, such as a complex matrix structure for the supervision of traders in the SCG, were too complicated and fragmented. Some individuals within the control functions lacked a clear understanding of the responsibilities that had been assigned to them' (UBS AG, p. 4).

Similarly, in the RBS case, the FCA found that 'overly complex and fragmented recording and reporting Systems required significant work to ensure they were effective ... (the Company) failed to appreciate the full scale of the reporting problems across the business' (RBS, p. 3).

This is consistent with the financial trading literature, where it is argued that without an effective and transparent risk escalation process (e.g. ensuring front-line personnel are willing to report problems), risk managers will struggle to measure, assess, control or manage the risks within the organisation (Bryce et al. 2013; Wahlstrom 2006). In relation to the FNs, it appeared that the lines of supervision were blurred by complex and fragmented supervision and the coordination and communication of information was disrupted within and across the teams. This reduced the ability of the operational staff to gather and interpret relevant safety information and make appropriate safety decisions. Future research is required to examine the impacts of this fragmentation, with System Implementation being important for ensuring clear lines of reporting and access to relevant information for decision-making.

\section{Emergent Theme of Organisational Incentives}

In addition to the synergies between the safety culture literature and the Final Notices, it is notable that, across all of the cases, organisational incentives were identified as a cause of employee risky and unethical behaviours.

For example, investigation of the Final Notices reveals several instances where conflicts of interest between work (e.g. profit generation) and safety (e.g. regulatory adherence) exacerbated the trading mishaps. This is a classic indicator of safety culture (Flin et al. 2000) and illustrates how the failure of active trading strategies can lead to fiscally disastrous consequences. Many of the riskier trading strategies (e.g. JPMorgan Chase Bank N.A.) were allowed to continue in a desire to post stronger gains and avoid financial penalties, and decisions were made without a full appreciation of the risks involved. The profit-making interests of the management conflicted with the realities of the market and led to situations where traders were forced to decide between one outcome (follow management directive) and another (publish in line with the market). In the case of UBS AG, these 'mixed messages' had disastrous consequences, as increased media scrutiny regarding its submissions process and speculations about its credit worthiness led to the dissemination of informal directives by group management to 'protect our franchise in these sensitive markets' (UBS AG, p. 4). In turn, traders and submission staff continued to collude with other market players in order to stem the publishing of daily losses. The conflict of interest between organisational interests (e.g. making profit) and client or wider market interests (e.g. in the fair valuation of the underlying assets) are cited by the FCA as key findings in all ten of the cases reviewed.

In terms of the safety culture literature, incentives are generally not included as a dimension of safety culture. This is perhaps because, in many high-risk domains, financial incentives are not used to the same extent as a reward (or otherwise) for performance. Yet, they appear crucial for the trading domain (and in particular, for shaping trader activity), and merit being considered as a distinct dimension.

\section{Discussion}

In this study, we examined the role of safety culture in ten high-profile organisational failures in the UK financial trading industry.

First, we found that dimensions of safety culture were routinely identified as underlying failures in financial trading organisations, for example in terms of how management attitudes regarding negative performance influenced traders to submit false prices in order to achieve productivity goals. 
Second, based on the absence and presence of safety culture dimensions identified within the FNs, an initial framework of cultural dimensions for measuring and evaluating safety culture in financial trading was developed.

Third, through examining how the specific dimensions of safety culture related to risk practices reported in the Final Notices, their utility for explaining risky and unethical behaviour in financial trading was examined, for example in terms of how Management Commitment to Safety influenced trader pricing positions, Risk Management influenced risk escalation and System Implementation compromised the ability of management to detect warning signals.

\section{Theoretical Implications}

In financial trading, risky and unethical employee practices do not necessarily lead to loss of life, but can have a huge impact upon economic and social structures. The current analysis indicates the relevance of safety culture for understanding mishaps within the financial industry. Financial trading was conceptualised in terms of high-reliability industries, whereby risky and unethical behaviours are understood as a product of organisational environments, with poor practices reflecting management priorities, inadequate safety Systems and a lack of training and communication.

Yet, it is notable that financial trading also differs substantially from most high-risk domains where safety culture is applied. Commonly, in such domains, risk is something to be mitigated or removed from a system. However, in financial trading, risk-taking is key to profit and competitive advantage and this changes how safety culture is conceptualised within financial trading (e.g. in comparison with aviation). Consistent with 'risk culture' research (Ashby et al. 2012), safety culture in financial trading refers more to the extent to which employees are implicitly or explicitly encouraged to take risks where long-term costs are significant, but are outweighed by short-term gains for the organisation and employees. For example, the FNs illustrate how various organisational issues (fragmented Systems and controls) and behavioural practices (ability to escalate an incident), regulation (inconsistent distribution of information regarding safety rules) and incentives (the prioritisation of profit over market compliancy) lead to poor employee risk practices.

It is noticeable that there are also broad similarities between the dimensions of safety culture identified in Box 2 and the Institute of Risk Management's (IRM) 'Risk Culture Aspects Model'. For example, selected themes identified in IRM's model such as 'tone at the top' and 'governance' map well onto the behaviours indicated in Box 2 under 'Management Commitment to Safety' and 'Rules and Regulations' (Institute of Risk Management 2012). These similarities provide further evidence of the applicability of a safety culture framework in this domain, indicating that the application of a safety culture framework is not only fitting, but that it can enrich the existing models though a deeper understanding of the specific behaviours that underlie the incidents. Drawing on previous safety culture research (Antonsen 2012) it is also indicative of the interventional steps that might be taken to improve safety culture in these settings (such as team training, incident reporting and monitoring and organisational learning exercises).

Future investigations might focus on refining the dimensions identified as underpinning safety culture in financial trading. For example, our analysis of Management Commitment to Safety and incentive structures reveals that employee's perception of management prioritisation (and how they are rewarded) influences risky and unethical behaviours. This might be useful to explore further. For example, by focusing on the priority workers place (and lengths they will go to) on securing financial rewards and avoiding penalties, we can better understand how pressure from a superior can lead to unsafe behaviour. Crucially, the predictive validity of safety culture theory for predicting or reducing mishaps in financial trading is required to demonstrate its ultimate utility. This can be achieved through the development of rigorous and psychometrically robust tools for measuring safety culture in financial trading.

\section{Practical Implications}

Although this industry is not a tabula rasa in terms of tools to analyse risk culture (e.g. surveys, structured questionnaires and scorecards), we aimed to empirically inform current approaches through adopting a safety culture perspective (Institute of Risk Management 2012).

The framework presented in Box 2 is a first step in achieving this and can inform the development of culture measurement tools in financial trading. The form of these tools may be diverse (see Guldenmund 2000, for a review); however, the most common procedure for collecting safety culture data is the use of employee cross-sectional surveys. Through a series of questions, surveys typically measure staff at all levels of an organisation on their beliefs, values, attitudes and perceptions towards risk. Data are associated with organisational outcome data and triangulated against other culture indicators data (e.g. incident reports, customer evaluations). 
Box 2 outlines the potential dimensions of a safety culture survey, and a safety culture assessment would examine the strengths, weaknesses and conflicts (e.g. between management and employees) on each cultural dimension. This typically leads to remedial action: for example training, modification of key processes, communication from management (Mearns et al. 2013). Such data also allow for benchmarking and inter-organisational learning, which is routine practice within aviation, energy and nuclear power (Carroll 1998; Mearns et al. 2001; Noort et al. 2015). As our current research is limited by the use of only one data source, we propose the development and testing of a survey tool with the participation of employees in different financial institutions internationally. This would be of considerable use for financial trading organisations (e.g. for learning about their culture, addressing problems) and regulators (e.g. to identify best practice, and problematic organisations). In addition, research might examine whether the safety culture model needs further adaptation to reflect the different nature of organisations working in the financial sector (e.g. asset-driven organisations versus speculative trading houses).

Alternative approaches to examining safety culture may not focus on perceptions of risk practices, but instead gather behavioural data, for example, through systematically collecting and analysing data on trading incidents. Such incidents can contain valuable data for avoiding future mishaps (on poor working practices, IT Systems) and for monitoring risk. Where incidents are reported voluntarily by staff, this can be highly symbolic of the culture (as it indicates a 'just' and 'mature' culture), whilst also revealing issues within the culture (e.g. on the pressures being experienced by staff). These approaches (surveys, incident reporting Systems) are mainstay approaches to monitoring risky and unethical practices in other highrisk domains and would appear equally useful for financial trading.

\section{Limitations}

This study has the following limitations. First, the literature review for identifying safety culture studies was not comprehensive, and it may have failed to capture other dimensions of safety culture important for financial trading. Second, the use of FCA FNs is only one method of collecting data on safety culture in the finance domain and the data have not been triangulated with other forms of data. This may lead to methodological bias, such as common method bias, with assumptions being based on one form of data and analysis (Podsakoff et al. 2003). Furthermore, the use of FNs as the data source also produces a limitation as they are considered secondary sources and their accuracy is difficult to confirm. Third, there are limitations in interrater coding. As the level of discrimination is quite high in the analysis of textual data with several dimensions, reliability is more difficult to assess and careful training of the coders is crucial. Also, judgements about the level of kappa that is deemed acceptable in the literature vary and should be considered in the interpretation of the results. Lastly, there are other existing culture-based theoretical lenses beyond safety culture that could be adopted to analyse these cases such as a competing values framework. For example, the competing values framework is a widely used cultural framework for profiling the culture of organisations (for a full review, see Cameron and Quinn 2005).

\section{Conclusions}

Culture measurement and change has previously been identified as crucial for restoring trust, improving Risk Management and avoiding future failures in financial institutions (House of Commons Treasury Committee 2009; Parliamentary Commission on Banking Standards 2013). Yet, a clear conceptualisation of what the desired culture for the industry is, and how it might be measured, is currently lacking (Power et al. 2013; Ring et al. 2016). To address these challenges, we examined whether, akin to other high-risk industries, safety culture theory provides a useful conceptual framework for understanding failures to manage risk in financial trading.

Through applying safety culture theory to analyse ten trading mishaps published in the FCA Final Notices, the study found that dimensions of safety culture were routinely identified as underlying failures in financial trading organisations. This counters narratives focusing on traders as unethical 'rule breakers' and instead emphasises the influence of social environments upon behaviour in financial institutions. To investigate this, the study developed an initial framework of cultural dimensions for measuring and evaluating safety culture in financial trading and examined how these dimensions were associated with the specific risk-related activities reported in the Final Notices. The results indicate that safety culture is a useful conceptual framework through which to understand and predict risky and unethical behaviour in financial trading, and can also inform the development of tools for assessing and invoking culture change.

Funding This study was not funded by any grant or organisation.

\section{Compliance with Ethical Standards}

Ethical Approval This article does not contain any studies with human participants or animals performed by any of the authors. 
Conflict of Interest Author Meghan P Leaver (first author) declares that she has no conflict of interest. Author Tom W Reader (second author) declares that he has no conflict of interest.

Open Access This article is distributed under the terms of the Creative Commons Attribution 4.0 International License (http://crea tivecommons.org/licenses/by/4.0/), which permits unrestricted use, distribution, and reproduction in any medium, provided you give appropriate credit to the original author(s) and the source, provide a link to the Creative Commons license, and indicate if changes were made.

\section{References}

Amalberti, R. (2013). Navigating safety: Necessary compromises and trade-offs. Theory and practice. Heidelberg: Springer.

Antonsen, S. (2009). Safety culture and the issue of power. Safety Science, 47, 183-191.

Antonsen, S. (2012). Safety culture: Theory, method and improvement. London: Ashgate Publishing Ltd.

Ashby, S., Palermo, T., \& Power, M. (2012, November 1). Risk culture in financial organisations: an interim report. Centre for Analysis of Risk and Regulation and the University of Plymouth. Retrieved from http://eprints.lse.ac.uk/47488/1/Riskcultureinfi nancialorganisations\%2528published\%2529.pdf

Ashkanasy, N. M., Wilderom, C. P., \& Peterson, M. F. (2000). Handbook of organizational culture and climate. Beverley Hills: Sage.

Braun, V., \& Clarke, V. (2006). Using thematic analysis in psychology. Qualitative research in psychology, 3(2), 77-101.

Bryce, C., Cheevers, C., \& Webb, R. (2013). Operational risk escalation: An empirical analysis of UK call centres. International Review of Financial Analysis, 30, 298-307.

Cameron, K. S., \& Quinn, R. E. (2005). Diagnosing and changing organizational culture: Based on the competing values framework. New York: Wiley.

Carroll, J. S. (1998). Safety culture as an ongoing process: Culture surveys as opportunities for enquiry and change. Work and Stress, 12(3), 272-284.

Chen, A. Y., Sawyers, R. B., \& Williams, P. F. (1997). Reinforcing ethical decision making through corporate culture. Journal of Business Ethics, 16(8), 855-865.

Clarke, S. (1999). Perceptions of organizational safety: implications for the development of safety culture. Journal of organizational Behavior, 20(2), 185-198.

Clarke, S. (2006). The relationship between safety climate and safety performance: A meta-analytic review. Journal of Occupational Health Psychology, 11(4), 315.

Cohn, A., Fehr, E., \& Maréchal, M. A. (2014). Business culture and dishonesty in the banking industry. Nature, 516(7529), 86-89.

Cooper, M. D. (2000). Towards a model of safety culture. Safety Science, 36(2), 111-136.

Cox, S. J., \& Cheyne, A. J. T. (2000). Assessing safety culture in offshore environments. Safety science, 34(1), 111-129.

Dekker, S. (2012). Just culture: Balancing safety and accountability. London: Ashgate Publishing, Ltd.

Ek, ̊., Arvidsson, M., Akselsson, R., Johansson, C. R., \& Josefsson, B. (2003). Safety culture in air traffic management: Air traffic control. In The 5th USA/Europe ATM 2003 R\&D Seminar.

Erez, M., \& Gati, E. (2004). A dynamic, multi-level model of culture: from the micro level of the individual to the macro level of a global culture. Applied Psychology, 53(4), 583-598.

Farrington-Darby, T., Pickup, L., \& Wilson, J. R. (2005). Safety culture in railway maintenance. Safety Science, 43(1), 39-60.
Fleiss, J. L., \& Cohen, J. (1973). The equivalence of weighted kappa and the intraclass correlation coefficient as measures of reliability. Educational and Psychological Measurement, 33(3), 613-619. doi:10.1177/001316447303300309.

Flin, R., Mearns, K., O’Connor, P., \& Bryden, R. (2000). Safety climate: Identifying common features. Safety Science, 34, 177-192.

Flin, R., \& Yule, S. (2004). Leadership for safety: Industrial experience. Quality and Safety in Health Care, 13(2), 45-51.

FSA (Financial Services Authority). (2012). Risks to consumers from financial incentives GC 12/11. London: Guidance Consultation.

Gapper, J. (2011). How to be a rogue trader. New York: Portfolio/ Penguin.

Gilligan, G. (2011). Jérôme Kerviel the'Rogue Trader'of Société Générale: Bad Luck, bad apple, bad tree or bad orchard? The Company Lawyer, 32(12), 355-362.

Glendon, A. I., \& Stanton, N. A. (2000). Perspectives on safety culture. Safety Science, 34, 193-214.

Goncalves Filho, A. P., Andrade, J. C. S., \& de Oliveira Marinho, M. M. (2010). A safety culture maturity model for petrochemical companies in Brazil. Safety science, 48(5), 615-624.

Greener, I. (2006). Nick leeson and the collapse of barings bank: Socio-technical networks and the rogue trader. Organization, 13(3), 421-441.

Guldenmund, F. W. (2000). The nature of safety culture: A review of theory and research. Safety Science, 34(1), 215-257.

Hajmohammad, S., \& Vachon, S. (2014). Safety culture: A catalyst for sustainable development. Journal of Business Ethics, 123(2), 263-281.

Halligan, M., \& Zecevic, A. (2011). Safety culture in healthcare: a review of concepts, dimensions, measures and progress. BMJ quality \& safety, 20(4), 338-343.

Håvold, J. I. (2010). Safety culture and safety management aboard tankers. Reliability Engineering \& System Safety, 95(5), $511-519$.

Hofstede, G., Neuijen, B., Ohayv, D. D., \& Sanders, G. (1990). Measuring organizational cultures: A qualitative and quantitative study across twenty cases. Administrative Science Quarterly, $35(2), 286-316$

Hopkins, A. (2011). Risk-management and rule-compliance: Decision-making in hazardous industries. Safety Science, 49(2), $110-120$

IIF. (2009). Reform in the financial services industry: Strengthening practices for a more stable system. Washington. Retrieved from www.iif.com

Institute of Risk Management. (2012). Risk culture: Resources for practitioners. London. Retrieved from https://www.iia.org.uk/ media/329076/irm_risk_culture_-_resources_for_practitioners. pdf

Jeffcott, S., Pidgeon, N., Weyman, A., \& Walls, J. (2006). Risk, trust, and safety culture in UK train operating companies. Risk Analysis, 26(5), 1105-1121.

Jennings, M. M. (2008). Some thoughts on ethics, governance, and markets: A look at the subprime saga. Corporate Finance Review, 12(4), 40.

Kaptein, M. (2011). From inaction to external whistleblowing: The influence of the ethical culture of organizations on employee responses to observed wrongdoing. Journal of Business Ethics, 98(3), 513-530.

Kowal, S., \& O'Connell, D. C. (2014). Transcription as a crucial step of data analysis. In Uwe Flick (Ed.), Sage handbook of qualitative data analysis (pp. 64-78). London: Sage.

Land, C., Loren, S., \& Metelmann, J. (2014). Rogue logics: Organization in the grey zone. Organization Studies, 35(2), 233-253. 
Lawton, R. (1998). Not working to rule: Understanding procedural violations at work. Safety Science, 78(2), 77-95.

Leaver, M., Reader, T. W. (2016). Human factors in financial trading: An analysis of trading incidents. Human Factors, 58(6), 814-832.

Lee, T., \& Harrison, K. (2000). Assessing safety culture in nuclear power stations. Safety science, 34(1), 61-97.

Linsley, P. M., Shrives, P. J., \& Crumpton, M. (2006). Risk disclosure: An exploratory study of UK and Canadian banks. Journal of Banking Regulation, 7(3), 268-282.

Lu, C. S., \& Yang, C. S. (2011). Safety climate and safety behavior in the passenger ferry context. Accident Analysis \& Prevention, 43(1), 329-341.

Mcconnell, Patrick, \& Blacker, K. (2013). Systemic operational risk: Does it exist and if so, how do we regulate it? The Journal of Operational Risk, 8(1), 59-99.

McHugh, M. L. (2012). Interrater reliability: The kappa statistic. Biochemia Medica, 22(3), 276-282.

Mearns, K., Kirwan, B., Reader, T. W., Jackson, J., Kennedy, R., \& Gordon, R. (2013). Development of a methodology for understanding and enhancing safety culture in Air Traffic Management. Safety Science, 53, 123-133.

Mearns, K., Whitaker, S. M., \& Flin, R. (2001). Benchmarking safety climate in hazardous environments: A longitudinal, interorganizational approach. Risk Analysis. doi:10.1111/0272-4332. 214149.

Miihkinen, A. (2012). What drives quality of firm risk disclosure? The impact of a national disclosure standard and reporting incentives under IFRS. The International Journal of Accounting, 47(4), 437-468.

National Oil Spill Commission. (2011). Deep water: The gulf oil disaster and the future of offshore drilling. Washington, DC: U.S. Government Publishing Office.

Noort, M. C., Reader, T. W., Shorrock, S., \& Kirwan, B. (2015). The relationship between national culture and safety culture: Implications for international safety culture assessments. Journal of Occupational and Organizational Psychology, 89(3), 515-538.

Nordlöf, H., Wiitavaara, B., Winblad, U., Wijk, K., \& Westerling, R. (2015). Safety culture and reasons for risk-taking at a large steelmanufacturing company: Investigating the worker perspective. Safety Science, 73, 126-135.

Olive, C., O'Connor, T. M., \& Mannan, M. S. (2006). Relationship of safety culture and process safety. Journal of Hazardous Materials, $130(1), 133-140$.

Olsen, E. (2010). Exploring the possibility of a common structural model measuring associations between safety climate factors and safety behaviour in health care and the petroleum sectors. Accident Analysis \& Prevention, 42(5), 1507-1516.

Palermo, T., Power, M. and Ashby, S. (2016). Navigating institutional complexity: The production of risk culture in the financial sector. Journal of Management Studies, 54(2), 154-181.

Parliamentary Commission on Banking Standards. (2013). Changing banking for good: First report of session 2013-14. London: The Stationary Office Limited.

Paté-Cornell, M. E. (1993). Learning from the piper alpha accident: A postmortem analysis of technical and organizational factors. Risk Analysis, 13(2), 129-140.

Pidgeon, N. F. (1991). Safety culture and risk management in organizations. Journal of Cross-Cultural Psychology, 22(1), 129-140.

Pidgeon, N. (1998). Safety culture: Key theoretical issues. Work and Stress, 12(3), 202-216. doi:10.1080/02678379808256862.

Podsakoff, P. M., MacKenzie, S. B., Lee, J.-Y., \& Podsakoff, N. P. (2003). Common method biases in behavioral research: a critical review of the literature and recommended remedies. The Journal of Applied Psychology, 88(5), 879-903. doi:10.1037/0021-9010. 88.5.879.

Power, M. (2009). The risk management of nothing. Accounting, Organizations and Society, 34(6), 849-855.

Power, M., Ashby, S., \& Palermo, T. (2013). Risk culture in financial organisations. London School of Economics, pp. 1-78.

Reader, T. W., Noort, M. C., Shorrock, S., \& Kirwan, B. (2015). Safety sans Frontières: An international safety culture model. Risk Analysis, 35(5), 770-789.

Reader, T. W., \& O'Connor, P. (2014). The deepwater horizon explosion: Non-technical skills, safety culture, and system complexity. Journal of Risk Research, 17(3), 405-424.

Reason, J. (1998). Achieving a safe culture: Theory and practice. Work and Stress, 12(3), 293-306.

Reason, J., Parker, D., \& Lawton, R. (1998). Organizational controls and safety: The varieties of rule-related behaviour. Journal of Occupational and Organizational Psychology, 71(4), 289-304.

Reiman, T., \& Oedewald, P. (2004). Measuring maintenance culture and maintenance core task with CULTURE-questionnaire-A case study in the power industry. Safety Science, 42(9), 859-889.

Ring, P. J., Bryce, C., McKinney, R., \& Webb, R. (2016). Taking notice of risk culture-the regulator's approach. Journal of Risk Research, 19(3), 364-387.

Roulet, T. J. (2014). 'What Good is Wall Street?' institutional contradiction and the diffusion of the stigma over the finance Industry. Journal of Business Ethics, 130(2), 389-402.

Saini, A., \& Martin, K. D. (2009). Strategic risk-taking propensity: The role of ethical climate and marketing output control. Journal of Business Ethics, 90(4), 593-606.

Sants, H. (2010). Can culture be regulated? London. Retrieved from http://www.fsa.gov.uk/library/communication/speeches/2010

Sims, R. R., \& Brinkmann, J. (2003). Enron ethics (or: culture matters more than codes). Journal of Business Ethics, 45(3), 243-256.

Singer, S., Lin, S., Falwell, A., Gaba, D., \& Baker, L. (2009). Relationship of safety climate and safety performance in hospitals. Health Services Research, 44(2p1), 399-421.

Strauch, B. (2015). Can we examine safety culture in accident investigations, or should we? Safety Science, 77, 102-111.

Sutcliffe, K. M. (2011). High reliability organizations (HROs). Best Practice \& Research Clinical Anaesthesiology, 25(2), 133-144. Retrieved from http://yadda.icm.edu.pl/yadda/element/bwmeta1. element.elsevier-c81f628d-2444-3a6f-bf39-4f6587ad4bd0

Turner, B. A. (1994). Causes of disaster: Sloppy management. British Journal of Management, 5(3), 215-219. doi:10.1111/j.14678551.1994.tb00172.x.

Van Hoorn, A. (2015). Organizational culture in the financial sector: Evidence from a cross-industry analysis of employee personal values and career success. Journal of Business Ethics. doi:10. 1007/s10551-015-2932-6.

Wahlstrom, G. (2006). Worrying about accepting new measurements: The case of Swedish bankers and operational risk. Critical Perspectives on Accounting, 17(4), 493-522.

Weaver, S. J., Lubomksi, L. H., Wilson, R. F., Pfoh, E. R., Martinez, K. A., \& Dy, S. M. (2013). Promoting a culture of safety as a patient safety strategy: A systematic review. Annals of Internal Medicine, 158(5(2)), 369-374.

Wheatley, M. (2012). Our vision for enforcement. Retrieved from http://www.fsa.gov.uk/library/communication/speeches/2012

Wiegmann, D. A., Zhang, H., Von Thaden, T. L., Sharma, G., \& Gibbons, A. M. (2004). Safety culture: An integrative review. The International Journal of Aviation Psychology, 14(2), 117-134.

Young, B. (2011). Leadership and high-reliability organisations; Why banks fail. Journal of Operational Risk, 6(4), 67-87. 
Zohar, D. (1980). Safety climate in industrial organizations: Theoretical and applied implications. Journal of Applied Psychology, 65(1), 96.

Zohar, D. (2002). The effects of leadership dimensions, safety climate, and assigned priorities on minor injuries in work groups. Journal of Organizational Behavior, 23(1), 75-92.
Zohar, D. (2010). Thirty years of safety climate research: Reflections and future directions. Accident Analysis and Prevention, 42(5), $1517-1522$. 